\title{
Quality rating of desserts based on fruit and berry raw
} materials

\section{Iryna Koretska, Oleg Kuzmin, Volodymyr Poliovyk, Liudmyla Deinychenko, Ganna Berezova, Nataliia Stukalska}

\author{
National University of Food Technologies, Kyiv, Ukraine
}

Keywords:

Dessert

Fruit

Berry

Quality

Rating

\section{Article history:}

Received

01.02.2021

Received in revised

form 13.06.2021

Accepted

16.07.2021

\section{Corresponding \\ author:}

Iryna Koretska

E-mail:

tac16@ukr.net

\section{DOI:}

$10.24263 / 2310-$

$1008-2021-9-1-8$

\section{Abstract}

Introduction. The aim of the study is to study the rating of the quality of desserts based on a fruit and berry blended semi-finished product with an increased antioxidant capacity and improved sensory indicators.

Materials and methods. Fruit and berry blended semi-finished product based on apple and banana. Research methods: expert evaluation method; rating method of 20 flavor profile portrait descriptors; profile method on a 10-point scale of correspondence of intensities of sensation of aromatic and taste properties; redoxmetry - determination of antioxidant capacity; $p H$-metry.

Results and discussion. The article presents the results of the influence of decisive factors for the formation of qualitative characteristics of innovative desserts - such as sambuk. The analysis of the system approach on increase of quality of production is carried out. A model of the technological system has been developed. An explanation of the values of each subsystem, its components and functions.

Evaluation of dessert quality indicators is determined by obtaining the average value of individual descriptors. Sensory characteristics of the innovative dessert: homogeneous semi-thick consistency; the color corresponds to the fruit and berry raw material, uniform over the entire surface; the taste and smell are clean. Based on the obtained results, the rating of innovative desserts was calculated. The sample of dessert «Applebanana» has a higher rating-96.815 points compared to the control sample «Apple»-91.195 points, which is a value that is $5.8 \%$ more than the control.

The minimum theoretical value of redox potential $(R P)$ for wateralcohol infusions was obtained, which has a value $\left(E h_{\min }\right)$ from $277.2 \mathrm{mV}$ («Apple-banana») to $412.8 \mathrm{mV}$ («Apple»). The actual measured value of $R P$ infusions $\left(E h_{a c t}\right)$ - from $126 \mathrm{mV}$ («Apple-banana») to $318 \mathrm{mV}$ («Apple»). The hydrogen index for water-alcohol infusions has a value of $4.12 \mathrm{pH}$ units («Apple») to $6.38 \mathrm{pH}$ units («Apple-banana»). Wateralcohol infusions from plant raw materials have values of regenerative capacity (reduction energy $-R E$ ) in the range from $R E-94.8 \mathrm{mV}$ («Apple») to $R E-151.2 \mathrm{mV}$ («Apple-banana»). For the restaurant business in the production of desserts is promising apple-banana composition, which received increased antioxidant characteristics.

Conclusion. The use of fruit and berry raw materials for expanding the quality of desserts using the method of a comprehensive quality criterion and calculation of the rating of desserts is substantiated. 


\section{Introduction}

In modern conditions, consumers of restaurants recognize the quality of food (Shimmura et al., 2019) as a determining criterion (Matsuoka et al., 2020). «Food quality» means a set of characteristics that meet the identified or probable needs of the consumer. (Shimmura et al., 2020; Tanizaki et al., 2020). This involves the creation of new food that are in demand (Shimmura et al., 2020) by generating new ideas (Kim et al., 2018), taking into account the views of employees on business processes (development of innovative food, development of innovative drinks, improvement of existing technologies) (Shimmura et al., 2019).

To assess consumer quality of the restaurant's food, it is proposed to use indicators of the composition of the product range, its uniqueness, as well as the taste and appearance of food (Kuzmin et al., 2016; Muñoz-Leiva, Gómez-Carmona, 2019).

One of the directions of development of desserts (Saunders, 2020), in restaurants is the production of sweet food (Nepovinnykh et al., 2019) with the addition of vegetable raw materials and a high content of biologically active substances (Ferrante et al., 2020).

Currently, the use of vegetable raw materials (Andreou et al., 2018; Belemets et al., 2016; Fotakis et al., 2016; Hrabovska et al., 2018; Iannitti, Palmieri, 2009; Kochubei-Lytvynenko et al., 2017) in restaurant business is very relevant (Gubskyi et al., 2015; Deinychenko et al., 2020; Ianchyk et al., 2018; Niemirich et al., 2017; Sylchuk et al., 2017).

Current demand for high-quality vegetable raw materials involves the development of new technological methods for its preparation, with increased quality control, environmental friendliness, higher energy efficiency, lower cost and safer operation (Dainelli et al., 2008; Mujumdar, Law, 2010). These methods will allow to preserve biologically active substances (Swasdisevi et al., 2009) - volatile aromatic substances, phenolic compounds, reduce their losses (Pavlyuk et al., 2018), increase sensory properties (Mayor, Sereno, 2004).

Vegetable raw materials contain different chemical substances that display a broad spectrum of biological activities (Frolova et al., 2019; Gerolis et al., 2017; Kamdem et al., 2013; Pyrzynska, Sentkowska, 2019; Sentkowska, Pyrzynska, 2018; Siddiqui et al., 2018; Steenkamp et al., 2004; Wong et al., 2020).

They have gained growing interest among scientists and consumers due to their antioxidant properties (Breiter et al., 2011; Dube et al., 2017). The ability of plant phenolics to act as free radical scavengers has led to increased interest in their ability to act as antioxidants (Herrera et al., 2018; Humia et al., 2020; Keating et al., 2014; Oh et al., 2013). Antioxidants are able to reduce the output of oxidation products: hydroperoxides, alcohols, aldehydes, ketones, fatty acids.

At present, the antioxidant characteristics of all prescription components, food additives, biologically active substances and their combinations have not been sufficiently studied (Buglass et al., 2012; Grunert et al., 2018; Gullón et al., 2018; Gulua et al., 2018; Joubert, Beer, 2012; Kuzmin et al., 2020).

The most promising, due to high taste, tender, airy texture and attractive appearance, are jelly sweet food - «sambuk». Unfortunately, these products are high in calories - low in nutrients (Polyovyk et al., 2021).

Therefore, the issue of expanding the range, the search for new prescription components and processing modes, in order to meet not only the taste preferences of consumers, but also the growing demand for functional products for restaurants (Kim et al., 2018).

«Sambuk» as an independent dessert is an effective dish for targeted enrichment with

vitamins, minerals, dietary fiber and natural antioxidants (Koretska et al., 2020).

«Sambuk» dessert has a low nutritional value due to the fact that the largest share in the 
recipe is sugar, apple puree and egg white. These components provide strength and stability of the foam system and, due to the presence of apple pectin, promote the excretion of harmful substances from the human body. Sugar shows its technological properties, but gives the product excessive sweetness and high caloric content of the finished dessert (Alija, Talens, 2012; Koretska et al., 2020).

These circumstances determine the relevance of this work, which consists in the development of sweet food based on fruit and berry raw materials (Kurzer et al., 2020; Walrand et al., 2020) in the technology of restaurant business. Creating desserts with high antioxidant properties and improved sensory performance allows restaurants to create new food (Alija, Talens, 2012; García et al., 2015; Koretska et al., 2020), which distinguishes them from competitors, creating a favorable image of the institution, which cares about consumer protection.

The aim of the study is to study the rating of the quality of desserts based on a fruit and berry blended semi-finished product with an increased antioxidant capacity and improved sensory indicators.

To achieve this goal, the following research goals were set:

- Determine the minimum theoretical value of $R P\left(E h_{\min }\right)$, the actual measured value of $R P\left(E h_{a c t}\right)$, the hydrogen index of water-alcoholic infusions.

- Determine the values of the antioxidant capacity of fruit and berry raw materials in water-alcohol systems.

- To study the profile criterion of quality and rating of desserts.

\section{Materials and methods}

\section{Materials}

The object of research - technology of desserts.

The subject of research: protein model samples with sugary foods; puree from fruit and berry raw materials; desserts.

The study used protein model samples with sugary foods; puree from fruit and berry raw materials: apple, banana; desserts based on fruit and berry puree.

To prepare extracts from fruits and berries raw, use the following main raw materials: ethanol, alcohol, water, cardboard filter.

\section{Description of research procedure}

Preparation of infusions. Fruit and berry raw materials weighing $4 \mathrm{~g}$ were placed into the glass bottles, were filled by $100 \mathrm{ml}$ of alcohol solvent with volume fraction of rectified ethyl alcohol $40 \%$. The resulting infusions were cooled to $20{ }^{\circ} \mathrm{C}$ for 7 days, stirring periodically.

Next, the infusions were filtered and studies were performed to determine the indicators of active acidity, which was measured on a $\mathrm{pH}$ meter in the mode of $\mathrm{pH}$ measurement with a combined glass electrode. The redox potential $(R P)$ was measured in the potential measurement mode with a combined redoxmetric platinum electrode. 


\section{- Food Technology}

\section{Description of methods}

\section{Methods for determining antioxidant capacity}

$R P$ is an important indicator of the biological activity of solutions (Kuzmin O. et al., 2016; Merwe et al., 2017). It characterizes the deviation from the ionic balance of free electrons in a liquid medium. Changing the concentration of free electrons leads to a change in its electron charge and, accordingly, the $R P$. If the $R P$ is positive, it indicates the oxidizing ability of the solution, negative indicates recovery ability. The value of $R P$ allows to estimate the energy of processes, that is, characterizes the activity of ions in redox reactions (Bahir, 1999; Priluckij, 1997). Therefore, in order for the human body to optimally use in the exchange processes water-alcohol solutions and food, the $R P$ values must correspond to the $R P$ values of the internal environment of the organism, or have more negative values (Bahir, 1999).

To evaluate the antioxidant properties of the obtained water-alcoholic plant extracts, the method (Priluckij, 1997), based on the difference of $R P$ in inactivated inorganic solutions and complex biochemical media. The main criteria of this method were its clarity, simplicity, specificity, reproducibility of results and efficiency. A number of researchers also emphasize that method allows to determine the total antioxidant activity of liquid products, including in total in a complex mixture, and multifunctional antioxidants (Kuzmin et al., 2016).

Formula (1) holds for inactivated inorganic solutions in equilibrium. This formula links the active acidity of the $p H$ and the $R P$ (Priluckij, 1997):

$$
E h_{\min }=660-60 \cdot p H, \mathrm{mV} \text {, }
$$

where $E h_{\min }$ - the minimum theoretically expected value of the $R P$; $p H-$ active acidity of the test solution.

Acquired $R P$ values were compared with actual measurements of $E h_{\text {act }}$ solution. The change of the $R P$ toward the recovery energy $(R E)$ was determined by the formula (Priluckij, 1997):

$$
R E=E h_{\text {min }}-E h_{a c t}, \mathrm{mV}
$$

where $R E$ - the shift of $R P$ to the side of recovered meanings (resilence);

$E h_{\min }-$ minimal theoretically expected meaning of $R P$;

$E h_{\text {act }}$ - actual measured $R P$.

\section{Expert method of sensory evaluation}

The expert method of determination of values of indexes of quality is based on the account of opinions of group highly skilled specialists-experts. (The expert of - it a specialist on the certain type of object which owns the increased sensitiveness to properties of this object) (Kuzmin et al., 2016).

\section{Sensory imaging method}

Determination of quality indicators of desserts was carried out by visualization of sensory properties, taking into account the difference in descriptors. The assessment of the 
influence of plant materials on the quality indicators of desserts was carried out using the criterion in the form of the sum of the products of the constituent indicators. An important feature of this criterion is that samples are rejected (through the established critical limit) in which at least one of the quality indicators has a false representation (characterized by a small value that is undesirable for desserts). The criterion for the quality of desserts in a geometric interpretation determines the optimal variant with the largest area of the quality polygon, built using normalized dimensionless quality indicators:

$$
S=\sin \frac{2 \pi}{N} \cdot \sum_{j=1}^{N}\left(f_{j} \cdot f_{j+1}\right)
$$

where $f_{i}$ - the value of a specific indicator; $N$ - the number of samples.

The determination of the weighting coefficients of individual indicators and their descriptors was carried out using the Delphi method, an expert method for each group of indicators according to the average values of the descriptors of this group, provided that the sum of the indicators of the group is 10 points.

Determination of the rating of desserts was carried out as the sum of the sets of values of the average indicators of the descriptors by the product by the weight coefficient for each descriptor.

Determination of the priority (rating) of desserts is possible provided that weighting factors are used (according to a 10-point system) and the main indicators are recalculated into rating values:

$$
P=\sum_{i=1}^{n}\left(m_{i} \cdot p_{i}\right)
$$

where $m_{i}$ - the value of the weighting factor;

$p_{i}$ - value of the main indicator.

\section{Results and discussions}

The complex of theoretical and experimental studies made it possible to determine the direction and approaches to the development of scientifically based technologies of desserts such as «sambuk» prophylactic direction (Ferrante et al., 2020; Polyovyk et al., 2021).

The general characteristics of obtaining a complex indicator of the quality of a new product - a sweet dessert of the «sambuk» type have been substantiated (Table 1).

The creation of new prophylactic «sambuk» desserts provides for the following:

- scientific and technological substantiation of the recipe composition of desserts;

- determination of the main subsystems of dessert technologies that are being developed and their interrelationships;

- conducting an analysis of the functioning of the system and its effectiveness;

- research of quality indicators of the developed desserts;

- determination of the shelf life of finished products.

Dessert production technologies were formed on the basis of a system analysis, which provides for the branching of the production process as a system into subsystems, which makes it possible to obtain finished products with predictable properties. 
Innovation structure of a new product

\begin{tabular}{|l|l|}
\hline \multicolumn{1}{|c|}{ Index } & \multicolumn{1}{c|}{ Characteristic } \\
\hline Object of study & Dessert technology \\
\hline $\begin{array}{l}\text { Urgency of the } \\
\text { problem }\end{array}$ & $\begin{array}{l}- \text { Improving the consumer properties of desserts; } \\
- \text { Increasing nutritional value; }\end{array}$ \\
\hline $\begin{array}{l}\text { Problematic element } \\
\text { of the system }\end{array}$ & $\begin{array}{l}\text { Physicochemical indicators (pH level, redox potential, renewal } \\
\text { energy), sensory indicators }\end{array}$ \\
\hline Solution option & $\begin{array}{l}\text { Use of fruit and berry raw materials for the technology of sweet } \\
\text { desserts }\end{array}$ \\
\hline Product name & $\begin{array}{l}\text { Blended semi-finished products from fruit and berry raw } \\
\text { materials for the technology of sweet desserts }\end{array}$ \\
\hline Product concept & $\begin{array}{l}\text { Blended semi-finished products are ready-made semi-finished } \\
\text { products, the technological properties of which allow them to } \\
\text { be used as a basis for sweet desserts. The use of mixed semi- } \\
\text { finished products is based on the enrichment of sweet desserts } \\
\text { with useful nutrients, which leads to an improvement in sensory } \\
\text { indicators, an increase in nutritional and biological value }\end{array}$ \\
\hline Target segment & For use by a wide range of consumers \\
\hline $\begin{array}{l}\text { Competitive } \\
\text { advantages }\end{array}$ & $\begin{array}{l}\text { A multifunctional product with a balanced composition of } \\
\text { biologically active substances }\end{array}$ \\
\hline $\begin{array}{l}\text { Sensory } \\
\text { characteristics of the } \\
\text { product }\end{array}$ & $\begin{array}{l}\text { Blended semi-finished product has a homogeneous half- } \\
\text { thick consistency; } \\
\text { The color corresponds to the plant material, uniform over } \\
\text { the entire surface; } \\
\text { Taste and smell are clean }\end{array}$ \\
\hline Range & $\begin{array}{l}\text { Formed due to the variable components of the fruit and berry } \\
\text { raw materials of the blend }\end{array}$ \\
\hline
\end{tabular}

Taking into account the purpose of desserts, during the development of the technology, it became necessary to analyze the technological functions of the main components and adjust the recipe composition, which will make it possible to create a sweet dessert with an enriched composition presented in Table 2 .

Table 2

Functions of structure-forming components and systems

\begin{tabular}{|l|l|}
\hline \multicolumn{1}{|c|}{ The composition of the stabilization system } & \multicolumn{1}{c|}{ Technological function } \\
\hline Blended semi-finished product & Foam stabilization, gelation \\
\hline Egg white powder & Foaming \\
\hline Glucose-fructose syrup & Sweetener, foam stabilization \\
\hline Water & Recovery, dissolution \\
\hline
\end{tabular}

In modern conditions, in the development of new types of food products, the profile method of sensory assessment and computer modeling are widely used. At the same time, using model samples with different content of the innovative component, researchers try to take into account all possible positive and negative aspects of the created product. 


\section{Formation of the quality of the dessert}

The production of desserts requires quality control throughout the entire technological process of making a dish. The quality of the products of the establishments of the restaurant industry is formed at the stage of its development and is laid down in the regulatory documents. At the production stage, the necessary conditions are provided for preserving the properties of raw materials, imparting the desired technological and sensory indicators to the product, and neutralizing inedible components. Ensuring a given level of product quality depends on many factors, and above all on the clarity of the parameters formulated in the technological maps.

We analyzed (using the Ishikawa diagram) (Figure 1) the main factors that form the quality of a sweet dessert. This approach is a graphical way of researching and determining significant causal relationships and makes it possible to identify key relationships between various factors of the first order: raw materials and materials, manufacturing technology and process modes, equipment used, personnel qualifications and the duration of the technological process.

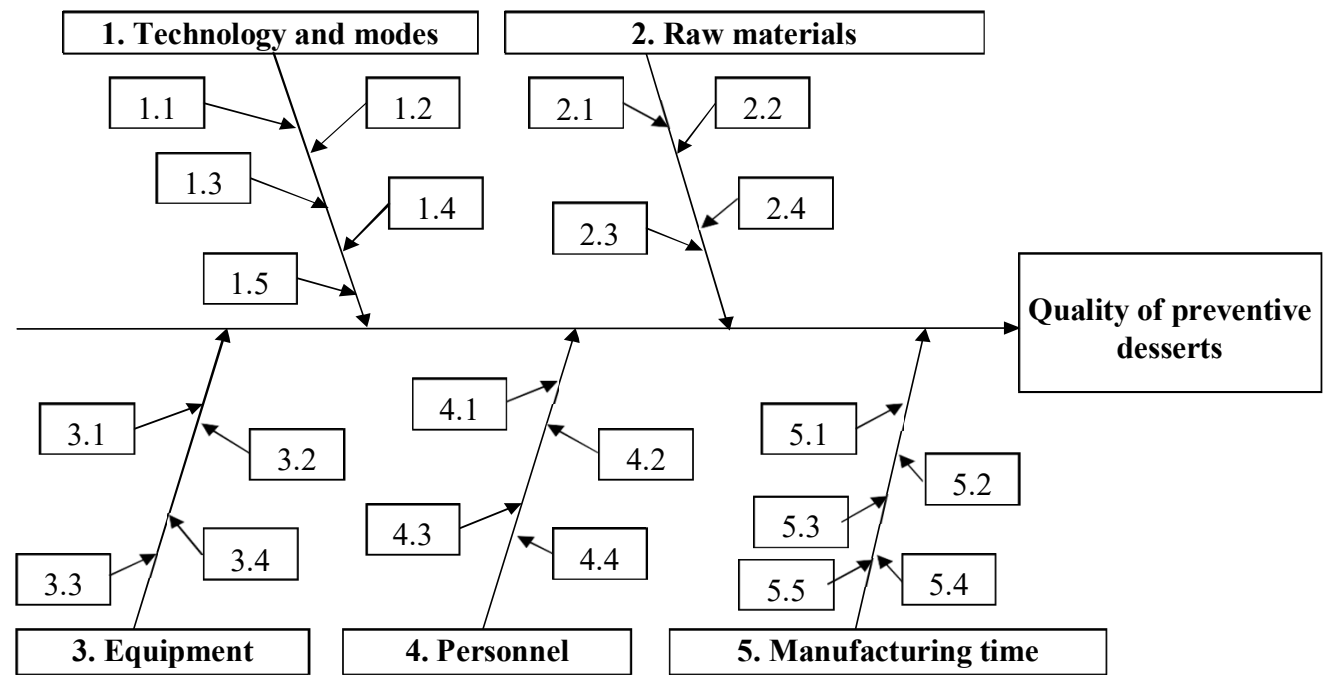

Figure 1. Causal diagram of the formation of dessert quality (Ishikawa diagram), second-order factors:

1.1 - compliance with the recipe; 1.2 - the sequence of introduction of components;

1.3 - compliance with the dosage of components; 1.4 - parameters of technological processes;

1.5 - sanitary and hygienic conditions; 2.1 - quality of basic raw materials;

2.2 - quality of blended semi-finished product; 2.3 - quality of auxiliary raw materials;

2.4 - compliance with the conditions of storage of raw materials;

3.1 - technical equipment of the enterprise; 3.2 - line performance; 3.3 - serviceability of equipment;

3.4 - the presence of control points; 4.1 - staff qualifications; 4.2 - experience of employees;

4.3 - diligence of staff; 4.4 - working conditions; 5.1 - timely preparation of components;

5.2 - timeliness of order acceptance (for restaurants) or availability of sales schedule (for

sanatoriums); 5.3 - the presence of apples; 5.4 - the presence of berry raw materials;

5.5 - the presence of glucose-fructose syrup 
For certain factors of the first level, we have established the factors of the second level, which are given under the main ones with the corresponding code. A number of factors are common in the manufacturing technologies of any culinary product and their effect is taken into account even at the stage of enterprise design. In order to improve the quality for readymade desserts, it is necessary to take into account the effect of all factors in the technological process. Second-order factors that are specific in the manufacture of a certain dessert provide for the features of the technologies being developed.

Taking into account such approaches to the creation of a new product, the authors proposed a model of the technological scheme (Figure 2).

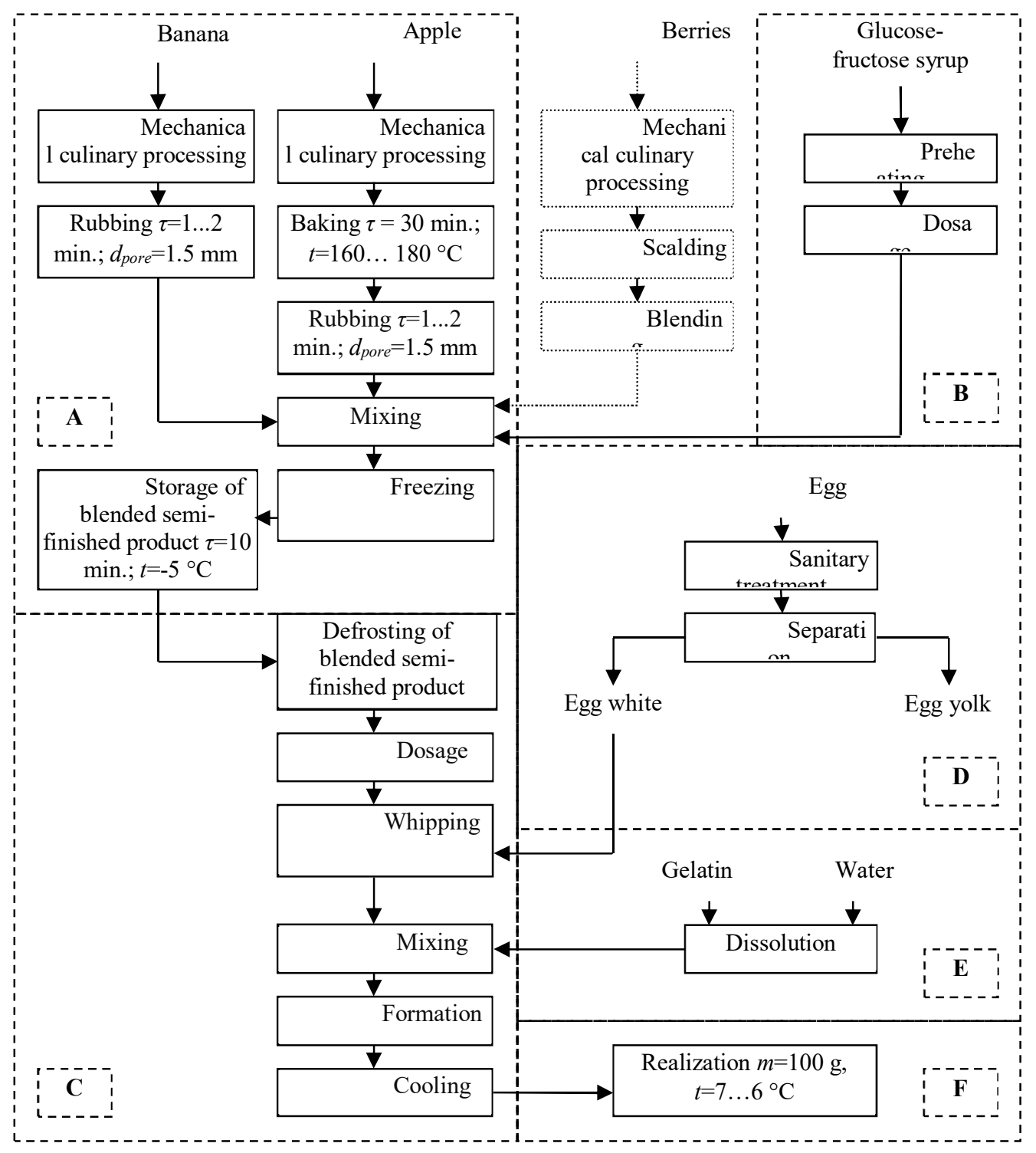

Figure 2. Model of the technological system «Production of whipped fruit and berry desserts of the «sambuk» type» 
Functions of the subsystems of the models of the technological system «Production of innovative desserts of the foamy structure of the sambuk type»:

Subsystems A-F: obtaining a fruit and berry dessert of a frothy structure such as a whipped sambuk with specified quality indicators.

Technological operations are performed within the A-E subsystems. Subsystem F leads to the realization of the dessert.

Subsystem A performs the following technological operations: mechanical culinary processing, baking, rubbing, mixing, freezing, storage of blended semi-finished product. Subsystem A: search for the necessary basis for desserts by consistency, chemical composition and glycemic index; preparation and formation of recipe composition. Subsystem A can have several alternative solutions. For example, mashed from cranberries, dogwood and other berry raw materials can be made next to the apple puree shown in the principle technological scheme. In the given model, each of the subsystems has certain functions and tasks.

The developed technology for making desserts in the formation of subsystem A provides, first of all, the preparation of a blended semi-finished product from apples and other vegetable raw materials, which includes a number of technological operations to bring it to readiness.

Subsystem B performs the following technological operations: preheating glucosefructose syrup and dosing it for subsystem A.

Subsystem C: an overview of technological approaches for creating a foamy base for the consistency of a dessert; obtaining a foamy consistency by determining the type and amount of the mass fraction of technological components, whipping time and mixing modes. In subsystem $\mathrm{C}$ the developed technology provides for the combination of vegetable fillers (blended semi-finished product, egg white, glucose-fructose syrup, water) and further whipping of the mixture.

Subsystem C: search for valuable plant raw materials from the point of view of chemical composition; study of the possible shape or consistency by introducing fruit and berry semifinished products as part of desserts; development of a technology for the production of mixed semi-finished products; research of the desired component composition, the change or composition of which will make it possible to form an assortment of desserts.

Subsystem D: the study of the quality of egg white. Subsystem D provides for the use of egg white, which is used to replace the native one in desserts. At the stage of subsystem C, mixing of egg white with fruit and berry puree is provided (Precup et al., 2020; Seçmeler, Sevimli, 2020) and mixing with subsystem $\mathrm{E}$ (gelatin dissolved in water) and creation of a recipe mixture (Zeeb et al., 2020).

It is proposed to add blended puree from fruit and berry raw materials to the composition of the dessert in the form of a blended semi-finished product as a biologically active component that compensates for the lack of trace elements and vitamins necessary for the full functioning of the body (González-Herrera et al, 2016; Jatav et al, 2018; Kalinowska et al., 2014; Koutsos, Lovegrove, 2015; Marcus, 2019; Massini et al, 2018; Nitcheu Ngemakwe et al., 2017).

On the basis of the developed model of the technological system «Production of fruit and berry desserts of a frothy mixture», basic technological schemes for the production of fruit and berry desserts of a foamy consistency were developed. 


\section{Sensory evaluation}

Based on the sensory assessment of sambuk samples, a quality criterion was calculated (based on the area of profilograms), which determines the overall comprehensive assessment of new desserts, and profilograms of the quality of sensory indicators for each dessert were constructed (Figure 3).

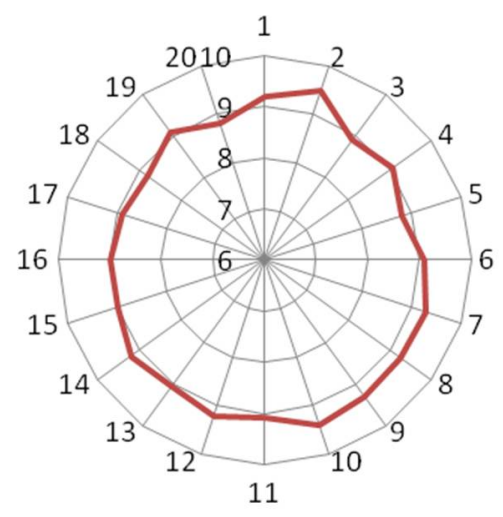

a

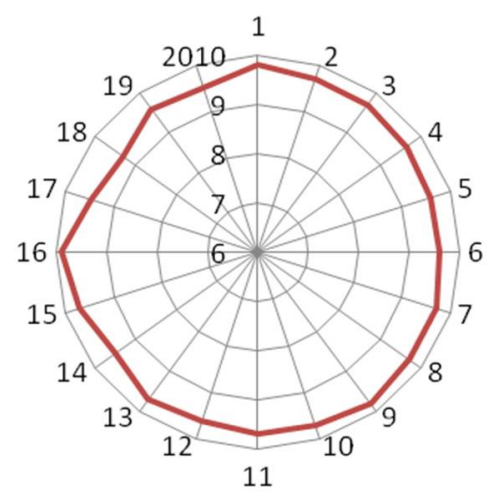

b

Figure 3. Dessert sensory profilograms:

$\mathrm{a}$ - apple; $\mathrm{b}$ - apple-banana; 1 - appearance; 2 - homogeneity of inclusions; 3 - naturalness; 4 - color; 5 - purity; 6 - uniformity of color; 7 - naturalness; 8 -taste; 9 - sweetness;

10 - intensity of the taste; 11 - uniformity; 12 - naturalness; 13 - smell; 14 - clean, 15 - expressive; 16 - balance; 17 - consistency; 18 - density; 19 - viscosity; 20 - fluidity

The quality of desserts was assessed by the following indicators: appearance (including color), taste, smell, and consistency. The value of the descriptors was taken into account when calculating the main indicator.

The weighting coefficients of individual indicators and their descriptors were determined by the Delphi method, by the expert method, for each group of indicators, according to the average values of the descriptors of this group and subject to the condition that the sum of the indicators of each group is 10 points (Table 3 ).

The final assessment of the quality indicators of desserts was determined by obtaining the average value of individual descriptors, which were used to determine this indicator by dividing the sum of the scores of all descriptors by their number. Using the results obtained, the desserts rating value was calculated.

The analysis of the rating of desserts showed that the sample «Apple-banana» has a higher rating indicator of 96.815 points compared to the control sample «Apple» $(91.195$ points).

The social effect of the new composition was confirmed - the preservation and protection of human health. This presupposes a more complete use of the nutritional potential of the raw materials used, an expansion of the assortment of desserts, an increase in their quality, an improvement in consumer properties, a decrease in the deficiency of vitamins, mineral elements and dietary fiber. This will ensure the normal functioning of the human body, satisfy consumer demand for desserts of functional importance. 
Indicators of the rating of desserts

\begin{tabular}{|c|c|c|c|c|c|}
\hline \multirow{2}{*}{$\begin{array}{l}\text { Indicators, } \\
\text { points }\end{array}$} & \multirow{2}{*}{ 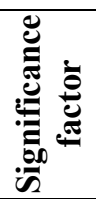 } & \multicolumn{2}{|c|}{$\begin{array}{c}\text { The value of individual } \\
\text { indicators }\end{array}$} & \multicolumn{2}{|c|}{ Rating value } \\
\hline & & $\begin{array}{l}\text { «Apple» } \\
\text { (control) }\end{array}$ & $\begin{array}{l}\text { «Apple- } \\
\text { banana» }\end{array}$ & $\begin{array}{l}\text { «Apple» } \\
\text { (control) }\end{array}$ & $\begin{array}{l}\text { «Apple- } \\
\text { banana» }\end{array}$ \\
\hline Appearance & 3.0 & 9.20 & 9.80 & 27.600 & 29.400 \\
\hline Color & 2.0 & 9.07 & 9.63 & 18.140 & 19.260 \\
\hline Taste & 2.0 & 9.25 & 9.70 & 18.500 & 19.400 \\
\hline Smell & 1.5 & 9.07 & 9.70 & 13.605 & 14.550 \\
\hline Consistency & 1.5 & 8.90 & 9.47 & 13.350 & 14.205 \\
\hline \multicolumn{4}{|c|}{ Rating, points } & 91.195 & 96.815 \\
\hline \multicolumn{4}{|c|}{ Quality criterion, point ${ }^{2}$} & 1656.04 & 1860.56 \\
\hline
\end{tabular}

Now at the international level there is an urgent problem of the production of desserts containing a high content of biologically active substances. Considering the dietary and functional purpose of desserts, it is advisable to introduce them into production, despite the increased selling price. New desserts can be consumed by all segments of the population, including those with diabetes mellitus.

\section{Antioxidant capacity}

Physicochemical studies, namely determination of the $p H$ level and $R P$ (Nicoli et al., 2004; Prévost, Brillet-Viel, 2014), were performed according to the method (Priluckij, 1997) and calculations given above (Kuzmin et al., 2016). As a result of extraction received infusions (Andreou et al., 2018; Iannitti, Palmieri, 2009; Kawa-Rygielska et al., 2019), physicochemical indicators (Breiter et al., 2011; Dube et al., 2017) of which are presented in the Table 4.

Table 4

Quality indicators of extracts on extractant

\begin{tabular}{|l|c|c|c|c|c|}
\hline \multicolumn{1}{|c|}{ Plant raw materials } & $\boldsymbol{t}^{\mathbf{0}} \mathbf{C}$ & $\boldsymbol{p H}$ & $\begin{array}{c}\boldsymbol{E} \boldsymbol{h}_{\boldsymbol{m i n}}, \\
\mathbf{m V}\end{array}$ & $\begin{array}{c}\boldsymbol{E} \boldsymbol{h}_{\text {act, }} \\
\mathbf{m V}\end{array}$ & $\begin{array}{c}\boldsymbol{R E}, \\
\mathbf{m V}\end{array}$ \\
\hline 1. Apple (control) & 20 & 4.12 & 412.8 & 318 & 94.8 \\
\hline 2. Apple-banana & 20 & 6.38 & 277.2 & 126 & 151.2 \\
\hline
\end{tabular}

where: $t$ - temperature of infusion; $p H$ - active acidity of the test solution; $E h_{\min }-$ minimal theoretically expected meaning of $R P ; E h_{a c t}$ - actual measured $R P ; R E$ - recovery energy

Figure 4 shows graphically the change in the physicochemical indicators of the quality of extracts of raw materials on the extractant.

The minimum theoretical value of $R P\left(E h_{\min }\right)$ for plant water-alcohol infusions (Priluckij, 1997) was obtained, which has a value from $277.2 \mathrm{mV}$ («Apple-banana») to $412.8 \mathrm{mV}$ («Apple»). The actual measured $R P$ of infusions $\left(E h_{a c t}\right)$ was established - from $126 \mathrm{mV}$ («Apple-banana») to $318 \mathrm{mV}$ («Apple»). The hydrogen index for water-alcohol infusions 
from raw materials has a value of 4.12 units $p H$ («Apple») to 6.38 units $p H$ («Applebanana»).

Water-alcohol infusions from vegetable raw materials and a volume fraction of ethanol of $40 \%$ have the value of regenerative capacity (recovery energy $-R E$ ) in the range from $R E$ - $94.8 \mathrm{mV}$ («Apple») to $R E-151.2 \mathrm{mV}$ («Apple-banana»). For the restaurant business in the manufacture of desserts, the apple-banana composition is promising, which has received increased antioxidant characteristics of $R E-151.2 \mathrm{mV}$.

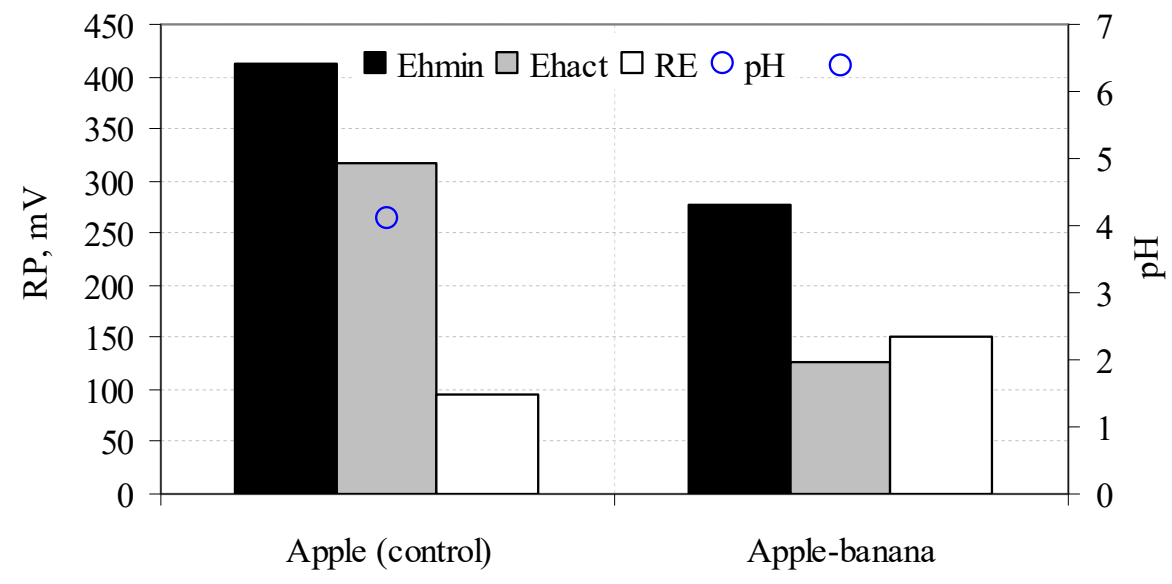

Figure 4. Physicochemical indicators of the infusions of the studied raw materials:

$\mathrm{pH}$ - active acidity of the test solution; $\mathrm{Eh}_{\min }$ - minimal theoretically expected meaning of RP; Ehact - actual measured RP; RE - recovery energy

The data obtained are correlated with the basic scientific concepts which are displayed in the works (Buglass et al., 2012; Frolova, Ukrayinets, 2018; Gerolis et al., 2017; Gullón et al., 2018; Gulua et al., 2018; Imark et al., 2000; Naithani et al., 2006; Naumenko et al., 2015; Pyrzynska, Sentkowska, 2019; Sentkowska, Pyrzynska, 2018), regarding the processes of extracting of plant materials. It allows to increase the antioxidant properties of the product (Breiter et al., 2011; Dube et al., 2017; Herrera et al., 2018; Keating et al., 2014; Vergun et al., 2019), will help to increase the immunity of the human body, improve the metabolism, positively affect the cardiovascular system, in addition it increases the consumer properties and will allow to reduce the cost of the finished product (Kumar et al., 2018; Peschel et al., 2006; Tan et al., 2020).

The development of a fruit and berry blended semi-finished product is a promising direction for increasing the nutritional value in the technology of desserts, expanding the assortment of the dessert group with predicted quality indicators. Its use ensures technological stability and high quality indicators of the finished product. The social effectiveness of the developments lies in the expansion of the assortment of desserts with a balanced dietary nutritional value and improved consumer properties. 


\section{Conclusions}

1. Determined the minimum theoretical value of $R P\left(E h_{\min }\right)$ for aqueous-alcoholic infusions, which ranges from $277.2 \mathrm{mV}$ («Apple-banana») to $412.8 \mathrm{mV}$ («Apple»). The actual measured value $R P\left(E h_{a c t}\right)$ is set - from $126 \mathrm{mV}$ («Apple-banana») to 318 $\mathrm{mV}$ («Apple»). The hydrogen index for aqueous-alcoholic infusions ranges from 4.12 $p H$ units («Apple») to $6.38 p H$ units («Apple-banana»).

2. The values of the antioxidant capacity of fruit and berry raw materials in water-alcohol systems have been determined. For the restaurant business in the production of desserts, the apple-banana composition is promising, which has received increased antioxidant characteristics of $R E-151.2 \mathrm{mV}$.

3. The profile criterion of quality and rating of desserts has been studied. An analysis of the dessert rating showed that the apple-banana sample had a higher rating score of 96.815 points compared to the apple control sample of 91.195 points.

\section{References}

Alija J., Talens C. (2012), New concept of desserts with no added sugar, International Journal of Gastronomy and Food Science, 1(2), pp. 116-122.

Andreou V., Strati I.F., Fotakis C., Liouni M., Sinanoglou V.J. (2018), Herbal distillates: A new era of grape marc distillates with enriched antioxidant profile, Food Chemistry, 253, pp. 171-178.

Bahir V.M. (1999), Sovremennye tehnicheskie jelektrohimicheskie sistemy dlja obezzarazhivanija, ochistki i aktivirovanija vody, VNIIIMT.

Belemets T., Yushchenko N., Lobok O., Radziyevska I., Polonskaya T. (2016), Optimization of composition of blend of natural vegetable oils for the production of milk-containing products, Eastern-European Journal of Enterprise Technologies, 5/11(83), pp. 4-9.

Breiter T., Laue C. Kressel G., Gröll S., Hahn A. (2011), Bioavailability and antioxidant potential of rooibos flavonoids in humans following the consumption of different rooibos formulations, Food Chemistry, 128(215), pp. 338-347.

Buglass A.J., Caven-Quantrill D.J. (2012), Applications of natural ingredients in alcoholic drinks, Natural Food Additives, Ingredients and Flavourings, 16, pp. 358-416.

Dainelli D., Gontard N., Spyropoulos D., Zondervan-van den Beuken E., Tobback P. (2008), Active and intelligent food packaging: Legal aspects and safety concerns, Trends in Food Science \& Technology, 19(1), pp. 103-112.

Deinychenko L., Deinychenko G., Gnitsevych V., Kravchenko T. (2020), Influence of processing parameters on the techno-functional properties of berry coagulants, Ukrainian Food Journal, 9(1), pp. 74-86.

Dube P., Meyer S., Marnewick J.L. (2017), Antimicrobial and antioxidant activities of different solvent extracts from fermented and green honeybush (Cyclopia intermedia) plant material, South African Journal of Botany, 110, pp. 184-193.

Ferrante M.J., Slejko G., Johnson S.L., Miller J., Bellows L.L. (2020), O19 Incorporating behavioral economic strategies into children's restaurant menus to improve healthfulness: parent perceptions, Journal of Nutrition Education and Behavior, 52(7), p. S9.

Fotakis C., Tsigrimani D., Tsiaka T., Lantzouraki D.Z., Zoumpoulakis P. (2016), Metabolic and antioxidant profiles of herbal infusions and decoctions, Food Chemistry, 211, pp. 963-971.

Frolova N., Ukrayinets A. (2018), Development of methods of production in natural aromatic production, Ukrainian Food Journal, 7(4), pp. 692-702.

Frolova N., Uktainets A., Korablova O., Voitsekhivskyi V. (2019), Plants of nepeta cat aria var. citriodora beck. and essential oils from them for food industry, Potravinarstvo Slovak Journal of Food 
Sciences, 13(1), pp. 449-455.

García V., Laca A., Martínez L.A., Paredes B., Rendueles M., Díaz M. (2015), Development and characterization of a new sweet egg-based dessert formulation, International Journal of Gastronomy and Food Science, 2(2), pp. 72-82.

Gerolis L.G.L., Lameiras F.S., Krambrock K., Neves M.J. (2017), Effect of gamma radiation on antioxidant capacity of green tea, yerba mate, and chamomile tea as evaluated by different methods, Radiation Physics and Chemistry, 130, pp. 177-185.

González-Herrera S.M., Rutiaga-Quiñones O.M., Rodríguez-Herrera R. (2016), Dehydrated apple matrix supplemented with agave fructans, inulin, and oligofructose, LWT-Food Science and Technology, 65, pp. 1059-1065.

Grunert K.G., Hieke S., Juhl H.J. (2018), Consumer wants and use of ingredient and nutrition information for alcoholic drinks: A cross-cultural study in six EU countries, Food Quality and Preference, 63, pp. 107-118.

Gubskyi S., Nikitin S., Evlash V., Niemirich O. (2015), Iodine content determination in dried talli of laminaria by galvanostatic coulometry, Ukrainian Food Journal, 4(2), pp. 320-327.

Gullón B., Eibes G., Moreira M.T., Herrera R., Gullón P. (2018), Yerba mate waste: A sustainable resource of antioxidant compounds, Industrial Crops and Products, 113, pp. 398-405.

Gulua L., Nikolaishvili L., Jgenti M., Turmanidze T., Dzneladze G. (2018), Polyphenol content, anti-lipase and antioxidant activity of teas made in Georgia, Annals of Agrarian Science, 16 (3), pp. 357-361.

Herrera T., Aguilera Y., Rebollo-Hernanz M., Bravo E., Martín-Cabrejas M.A. (2018), Teas and herbal infusions as sources of melatonin and other bioactive non-nutrient components, $L W T, 89$, pp. 65-73.

Hrabovska O., Pastukh H., Lysyi O., Miroshnyk V., Shtangeeva N. (2018), The use of enzyme preparations for pectin extraction from potato pulp, Ukrainian Food Journal, 7(2), pp. 215-233.

Humia B.V., Santos K.S., Schneider J.K., Leal I.L., Padilha F.F. (2020), Physicochemical and sensory profile of Beauregard sweet potato beer, Food Chemistry, 312, 126087.

Ianchyk M., Niemirich O., Vasheka O., Petrusha O., Pogozhikh N. (2018), Effect of banana powder and butter on the formation of the crystalline phase of sugar fondant, Eastern-European Journal of Enterprise Technologies, 4/11(94), pp. 35-41.

Iannitti T., Palmieri B. (2009), Antioxidant therapy effectiveness: an up to date, European Review for Medical and Pharmacological Sciences, 13, pp. 245-278.

Imark C., Kneubühl M., Bodmer S. (2000), Occurrence and activity of natural antioxidants in herbal spirits, Innovative Food Science \& Emerging Technologies, 1 (4), pp. 239-243.

Jatav S., Dwivedi P., Mishra B.B. (2018), Chapter 6: Properties and important molecules of medicinal interest in wood apple (Aegle marmelos), Synthesis of Medicinal Agents from Plants, pp. $127-150$.

Joubert E., Beer D. (2012), Phenolic content and antioxidant activity of rooibos food ingredient extracts, Journal of Food Composition and Analysis, 27(1), pp. 45-51.

Kalinowska M., Bielawska A., Lewandowski W. (2014), Apples: Content of phenolic compounds vs. variety, part of apple and cultivation model, extraction of phenolic compounds, biological properties, Plant Physiology and Biochemistry, 84, 169-188.

Kamdem J.P., Olalekan E.O., Hassan W., Kade I.J., Rocha J.B.T. (2013), Trichilia catigua (Catuaba) bark extract exerts neuroprotection against oxidative stress induced by different neurotoxic agents in rat hippocampal slices, Industrial Crops and Products, 50, pp. 625-632.

Kawa-Rygielska J., Adamenko K., Kucharska A.Z., Szatkowska K. (2019), Fruit and herbal meads - Chemical composition and antioxidant properties, Food Chemistry, 283, pp. 19-27.

Keating L., Hayes J., Moane S., Lehane M., Furey A. (2014), The effect of simulated gastrointestinal conditions on the antioxidant activity of herbal preparations made from native Irish hawthorn, Journal of Herbal Medicine, 4(3), pp. 127-133.

Kim E., Tang L.R., Bosselman R., (2018), Measuring customer perceptions of restaurant 
innovativeness: Developing and validating a scale, International Journal of Hospitality Management, 74, pp. 85-98.

Kochubei-Lytvynenko O., Marynin A., Yushchenko N., Kuzmyk U., Lazarenko M. (2017), Stude of the state of moisture in the curd paste with sumach extract and the addition of buckwheat groats, Eastern-European Journal of Enterprise Technologies, 6(90), pp. 22-26.

Koretska I., Polyovyk V., Maslikov M., Kuzmin O. (2020), Thermophysical characteristics of frozen semi-finished products for restaurant technology, Ukrainian Journal of Food Science, 8(2), pp. 231-240.

Koutsos A., Lovegrove J. A., (2015), Chapter 12: An apple a day keeps the doctor away-interrelationship between apple consumption, the gut microbiota and cardiometabolic disease risk reduction, Diet-microbe interactions in the gut, pp. 173-194.

Kumar V., Kushwaha R., Goyal A., Tanwar B., Kaur J. (2018), Process optimization for the preparation of antioxidant rich ginger candy using beetroot pomace extract, Food Chemistry, 245, pp. $168-177$.

Kurzer A., Wiriyaphanich T., Cienfuegos C., Spang E., Guinard J.-X. (2020), Exploring fruit's role in dessert: The Dessert Flip and its impact on university student acceptance and food waste, Food Quality and Preference, 83, 103917.

Kuzmin O., Kucherenko V., Sylka I., Isaienko V., Furmanova Y., Pavliuchenko E., Hubenia V. (2020), Antioxidant capacity of alcoholic beverages based on infusions from non-traditional spicyaromatic vegetable raw materials, Ukrainian Food Journal, 9 (2), pp. $404-424$.

Kuzmin O., Kovalchuk Y., Velychko V., Romanchenko N. (2016), Improvement technologies of aqueous-alcoholic infusions for the production of syrups, Ukrainian Journal of Food Science, 4(2), pp. 258-275.

Marcus J.B. (2019), Chapter 10: Recipes and menus that appeal to aging palates, Aging, nutrition and taste, pp. 339-428.

Massini L., Rico D., Martin-Diana A.B. (2018), Chapter 4: Quality Attributes of Apple Juice: Role and Effect of Phenolic Compounds, Fruit Juices, 24 November, pp. 45-57.

Matsuoka J., Tsurumine Y., Kwon Y., Matsubara T., Shimmura T., Kawamura S. (2020), Learning food-arrangement policies from raw images with generative adversarial imitation learning, 17th International Conference on Ubiquitous Robots, June 2020, pp. 93-98.

Mayor L., Sereno A. M. (2004), Modelling shrinkage during convective drying of food materials: a review, J Food Eng., 61(3), pp. 373-386.

Merwe J.D., Beer D., Swanevelder S., Joubert E., Gelderblom W.C.A. (2017), Dietary exposure to honeybush (Cyclopia) polyphenol-enriched extracts altered redox status and expression of oxidative stress and antioxidant defense-related genes in rat liver, South African Journal of Botany, 110, pp. 230-239.

Mujumdar A.S., Law C.L. (2010), Dry Technol: Trends and applications in postharvest processing, Food Bioprocess Tech., 3(6), pp. 843-852.

Muñoz-Leiva F., Gómez-Carmona D. (2019), Sparking interest in restaurant dishes? Cognitive and affective processes underlying dish design and ecological origin. An AMRI study, Physiology \& Behavior, 200, pp. 116-129.

Naithani V., Nair S., Kakkar P. (2006), Decline in antioxidant capacity of Indian herbal teas during storage and its relation to phenolic content, Food Research International, 39 (2), pp. 176-181.

Naumenko K., Petrusha O., Frolova N., Fedorenko O. (2015), Quality assessment of extracts from unconventional plant raw materials, Eastern-European Journal of Enterprise Technologies, 4(10), pp. 49-54.

Nepovinnykh N.V., Kliukina O.N., Ptichkina N.M., Bostan A. (2019), Hydrogel based dessert of low calorie content, Food Hydrocolloids, 86, pp. 184-192.

Niemirich O., Pogozhich M., Petrusha O., Havrysh A., Vasheka O. (2017), Restoring and emulsifying properties of the dried meat semi-finished product, Ukrainian Food Journal, 6(2), pp. 302-314. 
Nicoli M.C., Toniolo R., Anese M. (2004), Relationship between redox potential and chainbreaking activity of model systems and foods, Food Chemistry, 88(1), pp. 79-83.

Nitcheu Ngemakwe P.H., Remize F., Sivakumar D. (2017), Phytochemical and nutritional properties of underutilised fruits in the southern African region, South African Journal of Botany, 113, pp. 137-149.

Oh J., Jo H., Cho A.R., Kim S.J., Han J. (2013), Antioxidant and antimicrobial activities of various leafy herbal teas, Food Control, 31(2), pp. 403-409.

Pavlyuk R., Pogarskaya V., Cherevko O., Pavliuk V., Radchenko L., Dudnyk E., Radchenko A., Kolomiets T. (2018), Studying the complex of biologically active substances in spicy vegetables and designing the nanotechnologies for cryosupplements and nanoproducts with health benefits, EasternEuropean Journal of Enterprise Technologies, 4/11(94), pp. 6-14.

Peschel W., Sánchez-Rabaneda F., Diekmann W., Plescher A., Gartzía I., Jiménez D., LamuelaRaventós R., Buxaderas S., Codina C. (2006), An industrial approach in the search of natural antioxidants from vegetable and fruit wastes, Food Chemistry, 97(1), pp. 137-150.

Polyovyk V., Berezova G., Deinychenko L., Koretska I. (2021), Research of the process of desserts quality formation, Norwegian Journal of development of the International Science, 1(56), pp. 53-61.

Precup G., Mitrea L., Vodnar D.C. (2020), Chapter 8: Food processing by-products and molecular gastronomy, Gastronomy and Food Science, pp. 137-163.

Prévost H., Brillet-Viel A. (2014), Ecology of bacteria and fungi in foods, Influence of Redox Potential, Encyclopedia of Food Microbiology (Second Edition), pp. 595-601.

Priluckij V.I. (1997), Okislitel'no-vosstanovitel'nyj potencial dlja harakteristiki protivokislitel'noj aktivnosti razlichny napitkov $i$ vitaminnyh komponentov, Jelektrohim. aktivacija v medicine, sel. hozjajstve, prom-sti: I Mezhdunar. Simpozium.

Pyrzynska K., Sentkowska A. (2019), Herbal Beverages as a Source of Antioxidant Phenolics, Natural Beverages, 5, pp. 125-142.

Saunders A.B. (2020), Dairy Desserts, Reference Module in Food Science, Elsevier.

Seçmeler Ö., Sevimli Y. (2020), Chapter 9: Recipes for the valorization of culinary by-products and leftovers, Gastronomy and Food Science, pp. 165-192.

Sentkowska A., Pyrzynska K. (2018), Investigation of antioxidant interaction between Green tea polyphenols and acetaminophen using isobolographic analysis, Journal of Pharmaceutical and Biomedical Analysis, 15910, pp. 393-397.

Shimmura T., Nonaka T., Yamamoto T., Arai K. (2019), Introducing batch production and training game for enhancing both quality of dish and labor productivity at Japanese cuisine restaurant, Procedia CIRP13, 79, pp. 690-694.

Shimmura, T., Ichikari, R., Okuma, T. (2020), Human-robot hybrid service system introduction for enhancing labor and robot productivity, IFIP advances in information and communication technology, 592 IFIP, pp. 661-669.

Shimmura T., Ichikari R., Nonaka T. (2020), Service robot introduction to a restaurant enhances both labor productivity and service quality, Procedia CIRP, 88, pp. 589-594.

Siddiqui N.A., Al-Yousef H.M., Alhowiriny T.A., Alam P., Abdallah R.H. (2018), Concurrent analysis of bioactive triterpenes oleanolic acid and $\beta$-amyrin in antioxidant active fractions of Hibiscus calyphyllus, Hibiscus deflersii and Hibiscus micranthus grown in Saudi Arabia by applying validated HPTLC method, Saudi Pharmaceutical Journal, 26, pp. 266-273.

Steenkamp V., Fernandes A.C., Rensburg C.E.J., Jäger A.K. (2004), Antioxidant scavenging potential of South African export herbal teas, South African Journal of Botany, 70(4), pp. 660-663.

Swasdisevi T., Devahastin S., Sa-Adchom P., Soponronnarit S. (2009), Mathematical modeling of combined far-infrared and vacuum drying banana slice, J Food Eng, 92(1), pp. 100-106.

Sylchuk T., Bilyk O., Kovbasa V., Zuiko V. (2017), Investigation of the effect of multicomponent acidulants on the preservation of freshness and aroma of rye-wheat bread, Eastern-european journal of enterprise technologies, 5/11(89), pp. 4-9. 
Tan L., Nuffer H., Feng J., Kwan S.H., Chen H., Tong X., Kong L. (2020), Antioxidant properties and sensory evaluation of microgreens from commercial and local farms, Food Science and Human Wellness, 9(1), pp. 45-51.

Tanizaki T., Shimmura T., Fujii N., Rene A.O.N. (2020), Staff scheduling in restaurants where hall staff and robots cooperate, International journal of simulation and process modelling, 15(6), pp. $535-545$.

Vergun O., Svydenko L., Grygorieva O., Shymanska O., Rakhmetov D., Brindza J., Ivanišová E. (2019), Antioxidant capacity of plant raw material of Scutellaria baicalensis Georgi, Potravinarstvo Slovak Journal of Food Science, 13(1), pp. 614-621.

Walrand S., Wymelbeke V.V., Herpin F., Rigaudier F., Salles J., Laleg K., Bonhomme C., Hazart E., Salameh E., Allaert F.-A. (2020), A high-protein/high-energy fruit dessert is as effective as milkbased oral nutritional supplement to increase blood leucinemia in older women, Clinical Nutrition ESPEN, 40, pp. 584-585.

Wong F.C., Xiao J., Wang S., Ee K.Y., Chai T.T. (2020), Advances on the antioxidant peptides from edible plant sources, Trends in Food Science \& Technology, 99, pp. 44-57.

Zeeb B., Roth M., Endre H.U. (2020), Chapter 10: Commercial pectins, Handbook of Hydrocolloids (Third Edition), pp. 295-315. 